\title{
ROMA PEOPLE, WHERE TO? TRADITION AND CHANGE IN ROMA COMMUNITIES
}

\author{
MARIUS IMRE PARNO, MARIUS VASILUȚĂ-ȘTEFĂNESCU \\ Department of Sociology, West University of Timisoara, Romania
}

(C) 2021 Marius Imre Parno, Marius Vasiluță-Ștefănescu

This is an open access article distributed under the Creative Commons Attribution-NonCommercial-NoDerivs license (http://creativecommons.org/licenses/by-nc-nd/3.0/)

DOI: $10.2478 /$ eras-2021-0006

\begin{abstract}
Roma community in Romania is one of the largest ethnic communities in this country. Romani people integration and reducing disparities between the Roma community and the majority one is a priority for both the Romanian state and the Roma civil society. The integration of the Roma on the labor market is an important step in the integration process. This article proposes qualitative research through the interview method. The research question investigates whether traditional occupations practiced by Roma do not provide Roma access to the labor market today. The general objective of this study aims to identify and analyze qualitatively non-traditional socio-economic practices in the Roma communities in Timişoara and Cluj-Napoca. This objective has been operationalized in several specific objectives related to the identification of traditional economic practices in the occupations of members of the Roma communities in Timisoara and Cluj-Napoca, depending on membership in the subgroup / ethnic group, the identification of non-traditional economic practices in the occupations of members of the Roma communities in Timișoara and Cluj-Napoca, analysis of the role of traditional economic practices in preserving the lifestyle specific to the Roma ethnic group, as essential elements of culture in the communities of Timișoara and Cluj-Napoca. The last two objectives propose the analysis of non-traditional economic practices taken over in the occupations of the members of the Roma communities from Timişoara and Cluj-Napoca following the process of internal and external migration, respectively following the intervention of European funded programs. The participants of this research are 10 Roma people from Cluj-Napoca and 10 Roma people from Timişoara. The research results show that with industrialization, traditional occupations tend to limit their activity and integrated Roma people no longer practice the traditional occupations practiced by their parents or grandparents.
\end{abstract}

\section{Keywords}

Roma community, labor market, Roma ethnicity, Roma traditions, Romani language, non-traditional trades

\section{Introduction}

This article aims to contribute by clarifying the occupational field of the Roma population in the process of social integration. The integration of the Roma community is a priority for the Roma civil society, the Romanian state institutions, and for the European institutions, because the discrepancy between this community and the rest of the population is very substantial (Ionescu\&Cace, 2006, 67). In this regard, laws and directives have been issued and financial resources have also been allocated. "However, the Roma ethnic group and its culture, as distinct entity, were not acknowledged formally, institutionally, during the communist regime" (Zamfir, 2013, 155). Lately, the Roma problematic is approached both by the Romanian institutions and the European institutions because of the great and too wide disparities between the Roma community and the majority one (Zoon, 2001, 40).

This approach is carried out inside the community, knowing the mentality, difficulties, customs, and traditions of the Roma. "Most research on the Roma people has been done on the 
Roma, rather than with them" (Gomez, Racionero, \& Sorde, 2010, 28). Research within the community is quite rare since the number of experts in the field is quite limited. The interviewees in this research report honestly to someone of the same ethnicity.

In the first part of this article, we will present information about traditional occupations, customs and traditions, the role of qualifications in non-traditional occupations and Roma access to the labor market. The research methodology is a qualitative one. The technique used is the interview technique. In this research the tool used is the semi-structured interview guide. The participants of this research, 20 in total, are 10 Roma people from Cluj-Napoca and 10 Roma people from Timișoara.

\section{Traditional and non-traditional occupations of the Roma}

The Roma community is one of the most numerous ethnic groups in Romania today. "The Roma are now the largest ethnic minority on the continent, with a population estimated at 10 million to 12 million people" (Aiello, Mondejar, \& Pulido, 2013, 254). The first documents attesting their presence in the country date back to October 3,1385, when Voivode Dan I of Wallachia mentions in a document that, among many others, 40 gypsy families were given to a monastery in Tismana (Petcuț, 2009, 63). From that period, we meet three categories of slaves, namely: monastery slaves, princely slaves, and boyar slaves (Achim, 1998). After a long period of slavery, in the middle of the 19th century, the gypsies became free. Since the liberation, many Roma people have integrated (Potra, 2001, 105). Usually, Roma communities are located on the outskirts of cities or villages (Horvath, 2017, 195). Some compact communities keep their traditions, and they practice also traditional jobs.

This community first appeared in the Romanian space a few centuries ago. "The intersection of racial stigmatization and lower-class status initially drove the relocation of poor Roma people to the inner-city, and the housing tenure for many became increasingly precarious as time moved on" (Lancione, 2019, 185). The Romani language, the lifestyle, the customs, and the traditional occupations are culturally defining for this nation (Grigore \& Sarău, 2003).

The Roma community is divided into subgroups or Roma clans. The name of the clan is given by the profession practiced within the clan (Burtea, 2002). In the current context, with industrialization, we are witnessing a devaluation of traditional occupations due to the lack of a market for these specific trades. "High levels of poverty and unemployment, poor housing, limited access to health and welfare services mean that on average Roma live a decade less than their "non-Roma" compatriots" (Renzi, 2010, 55).

The Roma people who succeeded to integrate practice non-traditional jobs, and those who live in traditional communities practice traditional jobs (Ionescu, 2014). "Discrimination may be expressed in different ways, but in the case of Roma people it is believed to especially reflect poor access to education, limited employment opportunities, housing possibilities and politics" (Apelseth, 2013). Traditional occupations have been passed down from generation to generation, most of the time families have had to move from village to village from the beginning of winter until the end of autumn (Toma, Foszto, 2011). There are several Roma clans, each with its own occupation, its own rules, its own lifestyle, and social organization. Among these Roma clans we mention only a few, the most important: the Blacksmiths, the Fiddlers, the Florists, the Goldsmiths, the Spoitor clan, the Bearers, the Rudari clan, the Caldari - tinsmiths and coppersmiths and the Vatrashi (Burtea, 2002).

Lately, we have witnessed an occupational dynamic, namely some Roma people due to the lack of a market, have given up their old occupations in order to adapt the needs of the market. Over generations, people kept their Roma or Gypsy identity, but lost their national and clan identity related to their occupation. Having access to education and qualification courses carried out through European-funded projects, the number of Roma who have learned non- 
traditional occupations has increased (Salat, 2008, 41). They live among the majority population, have access to quality health services, education, a job, and a home that provides them with a decent living (Kiss, 2009, 85).

The Roma from residential segregated communities, with low or no education, represent a major problem, because their access to a non-traditional qualification is almost non-existent. The number of these Roma is very high reported to all Roma population. Only a few Roma people still practice their traditional occupations, namely: the Fiddlers, the Gabors, the Florists, the Caldari. These occupations are often untaxed. As much as a Roma nation tends towards integration or assimilation, the traditional occupational aspect, its customs and traditions diminish proportionately. Those who currently practice traditional trades have come to work or value their products or services abroad. These include the Gabors, the Florists, The Rudari, the Fiddlers and the Caldari (Sala, 2007). Many Roma work in agriculture abroad. As the number of Roma migrated abroad increased, they were forced to learn how to practice non-traditional occupations (Fleck \& Rughiniș, 2008).

\section{Research methodology}

In this research we have chosen a qualitative approach through the interview method and the tool used is the interview guide. In the interview guide we addressed the following topics related to the traditional and non-traditional occupations of the Roma people. The selection technique of the respondents was the snowball technique, the first respondents indicating the following interviewees (Rotariu \& Ilut,, 2001, 63).

The research assumption is formulated as follows: we consider that the traditional occupations practiced by Roma do not offer them access to the labor market at present: Are traditional Roma occupations still perceived by members of the ethnic group as appropriate for the present times? The general objective of this study aims to identify and analyze qualitatively non-traditional socio-economic practices in the Roma communities in Timissoara and ClujNapoca.

This objective has been operationalized in several specific objectives related to the identification of traditional economic practices in the occupations of members of the Roma communities in Timisoara and Cluj-Napoca, depending on membership in the subgroup / ethnic group, the identification of non-traditional economic practices in the occupations of members of the Roma communities in Timișoara and Cluj-Napoca, analysis of the role of traditional economic practices in preserving the lifestyle specific to the Roma ethnic group, as essential elements of culture in the communities of Timișoara and Cluj-Napoca. The last two objectives pursue the analysis of non-traditional economic practices taken over in the occupations of Roma communities' members from Timișoara and Cluj-Napoca following the process of internal and external migration, respectively following the intervention of European funded programs.

The technique used is that of interviewing. In this research the tool used is the semistructured interview guide. The participants of this research, 20 in total, are 10 Roma people from Cluj-Napoca and 10 Roma people from Timișoara. We selected these participants considering that we know Roma people from both municipalities. In the selection process, we considered the persons of different ages, with different level of education, men, and women. We also choose traditional Roma persons who practice traditional jobs and Roma persons who practice non-traditional jobs.

The topics were chosen in order to analyze Roma participation in economic life by practicing traditional or non-traditional occupations.

The topics were operationalized in discursive cores when elaborating the interview guide. 
The first respondents (selected using the snowball technique) directed us generally to the other interviewees, but others were selected due to personal relationship. (Rotariu, Ilut, 2001, 63).

\section{Results}

In the following, we will present the main results that emerge from the analysis of the topics in the research tool which reflect the identity profile of the respondents, the identification of traditional and non-traditional practices.

The first topic of discussion with the interviewees had an introductory role, presentation and personal biographical history ("Please tell me a few things about yourself")

Through the first question of the semi-structured interview guide used as a tool for this qualitative research, we wanted to gather some personal data about the interviewees, to allow them to present themselves freely, to speak about their educational path, family status, but also the Roma clan they belong to. This dependency is given by the spiritual values and by the economic factor. The individual receives inside his family affection for his personal development and skills to practice a job which in the future will be the source of his incomes. Depending on the values and their own traditions a family is considered conservative or integrated.

The main discursive nuclei that we identified after analyzing the answers are the following: self-esteem, belonging to a specific Roma clan, perception of education, but also interpersonal relationships in the family. The interviewees either did not express their selfesteem in any way, or they related positively to themselves by the way they talked about themselves. Regarding the clan they belong to, most of the research participants confirmed that they know their clan (Caldari, Gabors, Fiddlers), but there were also interviewees who stated that they do not even know its name.

\section{"I honestly don't know what Roma clan I belong to. Unfortunately, I don't know". (S7, 28 years old, Timișoara, post-secondary studies) \\ "I don't even know what to say about the clan, quite complicated". (S8, 46 years old, Timişoara, higher education)}

On the other hand, regarding the perception of education, the interviewees talked about their own experiences lived in childhood and related to the educational environment. So, they said that there were times in the past when they felt marginalized because of the ethnicity they belong to, and even their children face unpleasant situations because of this aspect now. These aspects of possible discrimination have been settled by the Order of the Minister of Education no. 6134/2016 regarding the prohibition of school segregation in pre-university education schools.

"Yes, the children behaved very badly, I am half gypsy, half African and the pain was even worse, my hair was curly, I was a mulatto, the children were oppressive, they offended me, I had nicknames and different names, they didn't play with me, I tried to buy friends, it was very difficult for me and I suffered a lot because of it, I was very introverted at maturity because of this fact, once I left for the West I managed to communicate, we are no longer seen as people from the circus , weird". (S15, 36 years old, Cluj-Napoca, secondary education)

"The school was not pleasant, I went to school, I did not know that the ethnicity matters, I did not make a difference, I did not know that I 
should not mention that I am Roma, on the first day I was sitting in the front row, I got up and put my name, ethnicity and religion, once everyone heard that I was a gypsy everything changed, the next day I moved in the back of the class and I stayed there until I finished school". (S12, 37 years old, Cluj-Napoca, high school studies)

After identifying the most frequent words used by the interviewees in the answers given to the first question, we developed the figure below (Figure 1) - the size of the words is given by the frequency/intensity of occurrences of the word in the text.

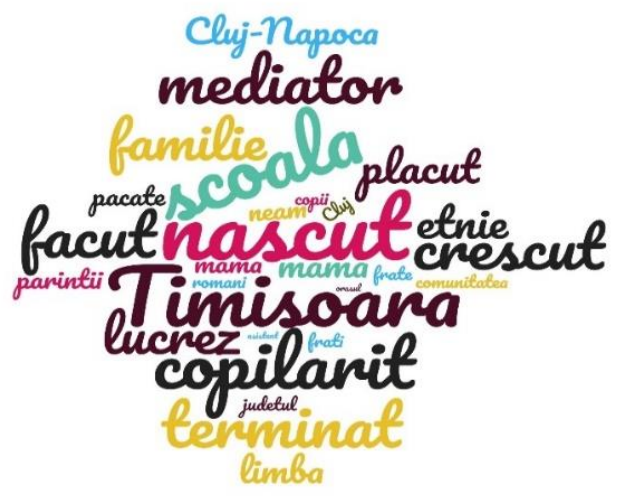

Figure 1. Intensity of words occurrences in text Source: own research

The main discursive cores identified based on the answers received from the interviewees are the following:

- Self-esteem (7 positive, 0 neutral, 0 negative)

- Belonging to a specific clan (3 positive, 1 neutral, 2 negative)

- Perception on education (3 positive, 1 neutral, 3 negative)

- Family (6 positive, 2 neutral, 1 negative)

The second topic aims to identify the level of satisfaction with the quality of life in relation to the city where the interviewees live or want to live: What is the city in Romania where you would like to live and work? Why?

Through this question we wanted to identify if the interviewees are satisfied with the conditions offered by the city where they live and if they would like to move to another city in Romania. There was a time when the internal migration was practiced at a very large scale. People migrated to industrialized areas, mining areas or to agricultural areas. Most of them established there with their families and other returned to their old homes. Later some of Roma people migrated to the big cities and remained in those areas.

Most of the interviewees said that they were satisfied with the place where they lived at that moment and the opportunities they are offered, but if they should choose another one, among the common answers were the following cities: Bucharest, Baia Mare, Brasov, Sibiu, Deva. 
"I would not move to another city. Bucharest is in the second place on the list. Ifeel a calling for Cluj". (S12, 37 years old, Cluj-Napoca, high school studies)

"Personally, I was once passing through Baia Mare and I liked this city, at least part of the city, from what I saw, and I said that if I were to move, I would move to Baia Mare, but not elsewhere". (S15, 36 years old, Cluj-Napoca, secondary education)

"I don't like Bucharest, being a crowded, big city, I didn't live in it... I don't know if I would adapt, although I am very sociable, but don't know... Cluj because there are material possibilities otherwise, you can work in 2-3 places if you have the strength and the mind ... it's something else... you also have places to visit ... you also have where to go out". (S16, 40 years old, Cluj-Napoca, higher education)

" I would choose Bucharest. Because it seems like a city to me, the capital of Romania, it's a big city and I've been to Bucharest before and it seemed and I thought it was such a good prospect, so how to say ... Timisoara has those things too, but in the capital it's a third of, a quarter of the country's economy. (S1, 41 years old, Timișoara, higher education).

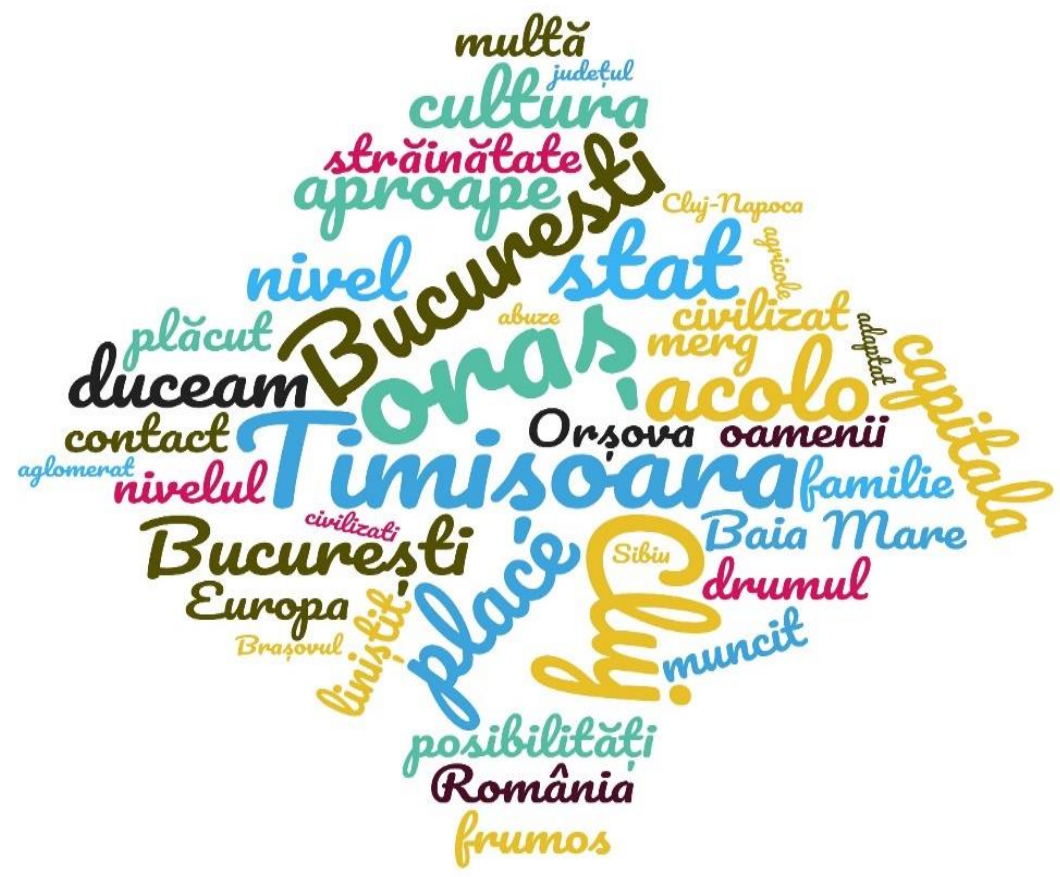

Figure 2. Intensity of words occurrences in text

Source: own research

The main discursive nuclei identified based on the answers received from the interviewees are the following:

$\checkmark$ Internal migration (8 positive, 5 neutral, 6 negative)

○ Timisoara (7 positive, 1 neutral, 1 negative) 
○ Cluj (5 positive, 2 neutral, 0 negative)

- Another city:

- Bucharest (4 positive, 1 neutral, 2 negative)

- Braşov (1 positive, 0 neutral, 0 negative)

- Sibiu (1 positive, 0 neutral, 0 negative)

- Baia Mare (1 positive, 0 neutral, 0 negative)

Migration motivation (5 positive, 10 neutral, 1 negative)

The third topic concerns the interviewees' participation in training courses financed by European funds: Did you or your family members participate in training courses financed by European funds and projects?

Through this question, we followed the participation of the interviewees in training courses financed by European funds and projects, and we wanted to find out the employees' perception on the increase of the job opportunities after their completion. Most of the interviewees participated in such training courses through European funding, themselves, and the members of their families also. The courses took place both in the country, through associations, or took place abroad (Belgium, Hungary, Bulgaria), and helped the interviewees either find a job or decide on the field in which they wished to operate at that time.

"Both me and my brother participated. I participated in the Sans Organization in Bucharest... which means health in Romanian, I did nursing school, having a scholarship from them... I think I received a scholarship from Hungary... from the Rome Open... I was the beneficiary of their scholarship program". (S16, 40 years old, ClujNapoca, higher education)

"Yes. Some from European funds, some paid out of my pocket. So, for example, I did the project management course in the RomaParty Pro Europe in Bucharest, it was a course of several days and they paid for everything. While I paid for the European funds processing expert course in Timisoara out of my own pocket, and I did it at the Chamber of Commerce, as well as the trainer course, I also paid for it, so I tried to develop personally and professionally. I liked it when there was European funding, but when it was the case, I also paid out of my own pocket, without anyone funding me further". (S5, 43 years old, Timișoara, higher education)

"Yes. I was able to help my wife to work as a caretaker of the elder, afterwards she attended some English language courses and also entrepreneurship. My sister also participated in a health mediator course. It was a project written by the County Council in 2007, I think. I helped ethnic Roma to enrol in courses so that they could earn some money. If they took a training course, they received an allowance”. (S10, 49 years old, Cluj-Napoca, high school studies)

On the other hand, one of the original answers belongs to an interviewee who did not participate in European funding programs because he always had the possibility to pay the courses from his own funds, without having to resort to external funds.

"I have a degree in vocational training, I have accessed and I have written projects, I write projects at the moment also, but I have never been qualified through a funded measure, and that is due to the fact that it was not necessary. I have always the material possibilities to access education regardless of the form and level they had". (S8, 46 years old, Timișoara, higher education). 


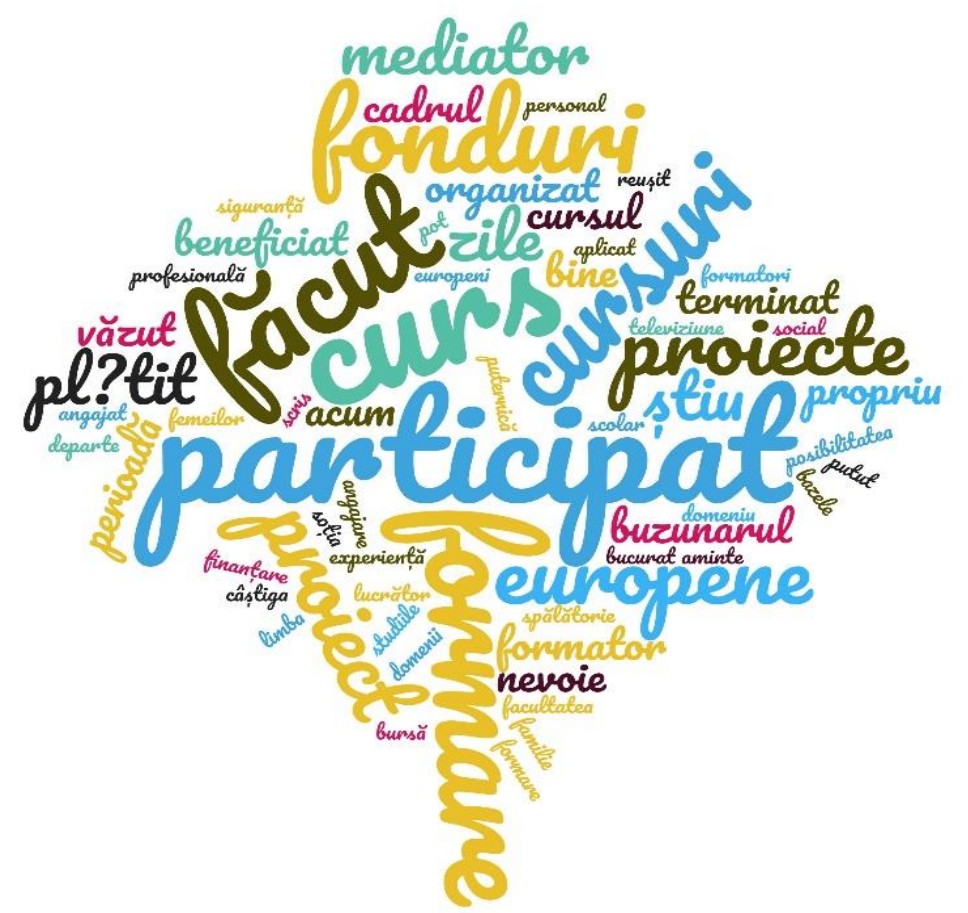

Figure 3. Intensity of words occurrences in text

Source: own research

The main discursive nuclei identified based on the answers received from the interviewees are the following:

$\checkmark$ Training courses through European funding (13 positive, 0 neutral, 4 negative)

$\checkmark$ Job obtained through training course (8 positive, 4 neutral, 4 negative)

The following topic addresses issues related to the following customs and traditions in the family of respondents: Are traditions followed in your clan? Do you and your family respect the traditions of the nation?

This question aimed at identifying the traditions of the clan to which each interviewee belongs, as well as whether the family or even the participant in this research respect the traditions or the use of the Romani language in everyday life. Same as other nations, Roma people have customs, traditions which define the ethnicity. One important element is the Roma language.

"I suppose that we each understand the definition of tradition according to our experiences, education and culture. When we talk about tradition, some things are similar. If we refer to the tradition of the clan I come from, those on my mother's side still keep some, if we speak on my father's side, no, because the situation in Banat was different. In Banat we don't find many communities that keep the Romani traditions. It depends, when we talk about tradition, we automatically talk about people's culture". (S8, 46 years old, Timişoara, higher education)

As I mentioned in the original answer above, tradition is understood differently by each person, therefore what for some interviewees may seem an element of tradition, for others it may be just an auspicious aspect, or a necessary one in the daily life (example: respect for the 
elderly, family reunions).

"Sure, sure, sure. First and foremost, as it is foremost of the people, it's the respect for those around us, including the elderly, such as parents, grandparents ... on one hand. On the other hand, you cannot go beyond the word of the elder. And the way we dress, our dress style is not like others with skirts or such, we have a more normal dress style, our girls also wear jeans". (S2, 31 years old, Timișoara, high school studies)

"Yes, it is generally respected, I don't know what traditions to tell you, the classic ones, I don't know... The fact that we all gather sometimes, for the holidays, and care about the family, since we live in Lugoj, for the Easter and Christmas holidays, all the time we meet with the whole family in the village where we are actually from, it's a reunion like this". (S6, 35 years old, Timișoara, vocational school)

Among the traditions that are still preserved today, we find mainly marriage at an early age, in terms of clothing - the wearing of long skirts by women or customs related to religion.

"Yes, not so much in my family, but I have some distant relatives who to some extent respect the traditions. For example: arranged marriages, that's about it”. (S3, 43 years old, Timișoara, higher education)

"Yes, you must get married early, you have to find a husband for your daughter early, you have to bring home your daughter-in-law early. In our country, the general dress of the Gabors is a bit, so not very wide, but not slim either. Well, the older people wear wider, lighter clothes as they used to wear, and we have remained traditional Gabors. Now some young people have changed and wear shorts, but in our country, it is a shame to wear very slim pants". (S4, 31 years old, Timișoara, secondary studies)

"We do not take into account traditions, we respect women, we have equal rights between the sexes, we do not keep traditions that denigrate people. A custom I keep from my grandparents is related to the fact that my grandfather never shaves on Sundays because he did not want to take down the image of Jesus, for example on Sundays we eat polenta with chicken stew... otherwise we do not take into account other habits”. (S12, 37 years old, Cluj-Napoca, high school studies). 


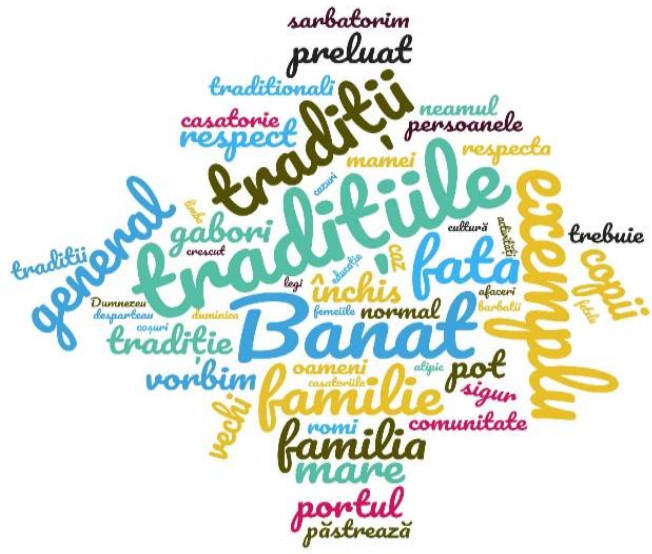

Figure 4. Intensity of words occurrences in text

Source: own research

The main discursive nuclei identified based on the answers received from the interviewees are the following:

$\checkmark$ Romani language (3 positive, 5 neutral, 2 negative)

$\checkmark$ Traditional behaviours and habits (7 positive, 4 neutral, 3 negative)

\section{Conclusions}

There is an interdependence between the questions from this study which lead to the confirmation of the research questions. The lack of qualitative schools and the discrimination proves that the educational path is very hard for most Roma people. The registration of large number of Roma children who drop out from school reduces the possibility of obtaining qualification in non-traditional jobs. The participants to this research assume belonging to Roma ethnic group but they know that they don't respect old tradition and, they don't practice traditional jobs. Most of the interviewed wish to migrate inside the country because they want a better life. They want to live in bigger towns.

Many of the Roma people participated in qualification courses through European funding projects. This reveals that the chances of Roma employment in traditional trades have increased. Most of the respondents say that in their family the Roma traditions are no longer respected. The old people keep old traditions, but the younger adapted to a different lifestyle. The process of the Roma assimilation is very hard, and it requires a long period of time to be completed.

\section{REFERENCES}

Achim, V. (1998). Țiganii în istoria României. Bucharest, Editura Enciclopedică.

Aiello, E., Mondejar, E., \& Pulido, M. A. (2013). Communicative methodology of research and recognition of the Roma people. International Review of Qualitative Research, 6(2), 254-265. DOI:10.1525/irqr.2013.6.2.254

Apelseth, F. H. (2013). The Roma people: the effects of discrimination on living standards, a case study of Kristiansand, Norway (Master's thesis, Universitetet i Agder; University of Agder). http://hdl.handle.net/11250/135279

Bănică, M. (2019). Bafta, Devla și Haramul, Studii despre cultura și religia romilor, Iași, Polirom Press. 
Creţan, R., Powell, R., 2018. The power of group stigmatization: wealthy Roma, urban space and strategies of defence in post-socialist Romania. Int. J. Urban Reg. Res. 42 (3), 423-441. https://doi.org/10.1111/14682427.12626

Dohotaru, A., Harbula, H., Vincze, E. (2016). Pata, Cluj-Napoca, Editura Fundației pentru Studii Europene.

Foszto, L. (2009). Colecție de studii despre romi din România, Cluj-Napoca, Editura Institutului pentru Studierea Problemelor Minorităților Naționale.

Gomez, A., Racionero, S., \& Sorde', T. (2010). Ten years of critical communicative methodology. International Review of Qualitative Research, 3, 17-43. https://doi.org/10.1525/irqr.2010.3.1.17

Grigore, D., Sarău, G. (2006). Istorie și tradiţii rrome, București, Editor Organizația Salvaţi Copiii.

Horvath, I., (2017). Raport de cercetare Socioromap. O cartografiere a comunităților de romi din România, ClujNapoca, Editura Institutul pentru Studierea Problemelor Minorităților Naționale.

Horvath, I., Nastasă, L., (2012). Rom sau Țigan. Dilemele unui etnonim în spațiul românesc, Cluj-Napoca, Editura Institutul pentru Studierea Problemelor Minorităţilor Naţionale.

Ionescu, M., (2014). Dezvoltarea socială a minorității romilor din România. Analiza instituțiilor, politicilor și a proiectelor naționale, Bucharest, Editura Pro Universitaria.

Kiss, T., Foszto, L., Fleck, G., (2009). Incluziune și excluziune Studii de caz asupra comunităților de romi din România, Cluj-Napoca, Editura Institutul pentru Studierea Problemelor Minorităților Naţionale.

Lancione, M. (2019). The politics of embodied urban precarity: Roma people and the fight for housing in Bucharest, Romania. Geoforum, 101, 182-191. https://doi.org/10.1016/j.geoforum.2018.09.008

Petcuț, P., (2009). Rromii din România. Documente, Cluj-Napoca, Editura Institutului pentru Studierea Problemelor Minorităților Naţionale.

Potra, G., (2001). Contribuțiuni la istoricul țiganilor din România, Bucharest, Editura Curtea Veche.

Preoteasa, A. M., Cace, S., Duminică, G. (2006). Strategia naţională de îmbunătățire a situației romilor: Vocea comunităților, Bucharest, Editura Expert.

Renzi, L. (2010). Roma people in Europe: A long history of discrimination. Eur Soc Watch Rep, 2010, 40-3.

Salat, L., (2008). Politici de integrare a minorităților naționale din România, Aspecte legale și instituționale întro perspectivă comparată, Cluj-Napoca, Centru de Resurse pentru Diversitate Etnoculturală.

Stănică, T., (2014). Kestiuni Rome. O incursiune în cultura, istoria și tradițiile romilor, Bucharest

Surdu, L., Vincze, E., Wamsiedel, M. (2011). Participare, absenteism scolar și experiența discriminării în cazul romilor din România, Bucharest, Editura Vanemonde.

Toma, S., Fozsto, L. (2011). Spectrum. Cercetări sociale despre romi, Cluj-Napoca, Editura Institutului pentru Studierea Problemelor Minorităţilor Naţionale.

Zamfir, E. (2013). Roma people within the global process of change. Revista de Cercetare şi Intervenţie Socială, (40), 149-165. https://www.ceeol.com/search/article-detail?id=92231

Zoon, I. (2001). La periferia societății. Rromii și serviciile publice în România, Cluj-Napoca, Open Society Institute 